\title{
TPACK Venn Diagram: Measuring the Balance of Implementation of Learning Models in Entering the Industry 4.0 era
} (Study on Geography Learning in 2013 Curriculum)

\author{
Ahmad Yani ${ }^{1}$, Mamat Ruhimat ${ }^{2}$, Asep Mulyadi ${ }^{3}$ \\ 1ahmadyani@upi.edu ,²mamatruhimat@upi.edu, 3asepmulyadi@upi.edu \\ 1,2,3 Department of Geography Education, Universitas Pendidikan Indonesia
}

Submitted

November 26, 2019
Revised

December 23, 2019

https://doi.org/10.17509/jpis.v28i2.21341
Accepted

December 23, 2019

\section{ABSTRACT}

This study tries to make a visualization of the three components of TPACK (Technological Pedagogical Content Knowledge) mastery in the form of a venn diagram. The research method used is descriptive with survey technique. The instruments used were questionnaires and interviews. The location of the questionnaire study consisted of West Java Province, Bengkulu Province, and other provinces that were filled out online through Google forms. Subjects were geography teachers with 121 respondents. Data obtained through questionnaires were analyzed in a quantitative manner while interview data were carried out qualitatively. The results of the study can make a hypothetical form of TPACK venn diagrams to illustrate the TPACK mastery profile of geography teachers, namely the slices price of TPACK (25\%), PCK (75\%), TCK (35\%), and TPK (15\%). The implication of obtaining the data is that policy makers can improve the competence of geography teachers starting from training on TCK and TPK.

Keywords: Venn Diagram, Geography, Industry 4.0, Curriculum 2013, TPACK

\begin{abstract}
ABSTRAK
Penelitian ini mencoba membuat visualisasi penguasaan tiga komponen TPACK (Technological Pedagogical Content Knowledge) dalam bentuk diagram venn. Metode penelitian yang digunakan adalah deskriptif dengan teknik survey. Instrumen yang digunakan adalah berupa kuesioner dan wawancara. Lokasi penelitian penyebaran angket terdiri dari Provinsi Jawa Barat, Provinsi Bengkulu, dan provinsi lainnya yang diisi secara online melalui google formulir. Subjek penelitian adalah guru geografi dengan jumlah responden 121 orang. Data yang diperoleh melalui kuesioner dianalisis dengan cara kuantitatif sedangkan data wawancara dilakukan secara kualitatif. Hasil penelitian dapat membuat bentuk hipotetik diagram venn TPACK untuk menggambarkan profil penguasaan TPACK guru geografi yaitu harga irisan TPACK (25\%), PCK (75\%), TCK (35\%), dan TPK (15\%). Implikasi dari peroleh data tersebut, pihak pengambil kebijakan dapat meningkatkan kompetensi guru geografi diawali dari peatihan tentang TCK dan TPK.

Kata Kunci: Diagram Venn, Geografi, Industri 4.0, Kurikulum 2013, TPACK
\end{abstract}

\section{INTRODUCTION}

The learning process is directed so that students can develop the ability to understand what they are learning through thinking skills [1]. In the learning process, teaching is a complicated

172 Ahmad Yani, et al.| TPACK Venn Diagram .... 
practice that requires intertwining various types of special knowledge [2]. Teachers are required to have three competencies at once namely mastering learning materials according to their field of study, mastering learning methods and strategies, and skilled in using technology, tools, and learning media. The three demands cannot be separated from one another, but must be integrated and concurrent in the implementation of learning. Teaching material must be understood by the teacher because it is the content of the material to be delivered. The learning strategy also needs to be mastered by the teacher so that it is effective and efficient in conveying learning material. Learning technology must also be mastered by teachers to strengthen learning strategies so that the achievement of learning objectives is more accelerated. Based on this understanding, the term Technological Pedagogical Content Knowledge (TPACK) emerged. TPACK emphasizes the relationship between technology, curriculum content, and certain pedagogical approaches [3]. TPACK has the potential to be useful in conceptualizing how technology costs can be utilized to improve teaching and learning [4]. In a number of references, TPACK can be used as a framework for developing learning models and at the same time evaluating the effectiveness of a learning model.

The concept of TPACK applies to all subjects. Conceptually, the 2013 curriculum cannot be implemented if it is not supported by the competence of teachers who master teaching materials, learning strategies, and learning technologies. The 2013 curriculum demands on teacher competency and the availability of learning technology is very high.
Especially if it is linked to the demands of industry 4.0, the implementation of 2013 Curriculum is increasingly pessimistic to be able to run well. 2013 Curriculum Design is considered very good, but the infrastructure has not been fully prepared.

This research will identify the readiness of schools in the implementation of the 2013 Curriculum, especially in geography in the industry 4.0 era. As already known before, the main vision of industry 4.0. is the emergence of smart factories that are connected to network facilities, the use of automation systems, artificial intelligence, and big data [5]. The learning process, which is usually limited by classroom walls, will shift to private spaces. Forms of technology and learning media that were in the form of analog teaching aids will shift to digitalbased media and can be accessed by students wherever and whenever [6]. Future learning systems will integrate cyber technology with artificial intelligence control systems in every laboratory practice and field observation.

The huge current changes in the industrial era 4.0 will also have an impact on teacher performance criteria. Call it the geography teachers; they are required to have competencies that are in line with the development of industry 4.o. One of the frameworks considered to measure teacher competence in the industry 4.0 era is Technological Pedagogical Content Knowledge (TPACK). This framework covers three core categories of knowledge: Content Knowledge (CK), pedagogical knowledge (PK), and technological knowledge (TK) [7]. In the aspect of Content Knowledge (CK), geography teachers are expected to have (1) an understanding of geographic concepts, 
principles and contexts that range from concrete concepts to abstract concepts; (2) the ability to explain geographic material, especially in linking one concept with another geographic concept; and (3) the ability to explain geographic material with a broader perspective for each case in different geographical locations. For this reason, it should be asked whether the geography teacher has attained the capabilities required above.

In addition, it is whether the geography teacher also has pedagogical knowledge in delivering geographic material (Pedagogical Knowledge). Finally, do they also master learning technology? Both of the above are worthy of being celebrated because as a general picture, teachers in Indonesia are generally still low in utilizing information and communication technology in the classroom. Gratitude has done research on 309 respondents from various levels and it turns out that about $25.89 \%$, teachers never use laptops for learning activities [8]. Other research is also the case, Nur'saban et al. conducting research on the pedagogical competence of high school geography teachers in Bantul Regency, particularly in utilizing information and communication technology, was also still lacking [9]. They are only able to use technology on a score of 2.5 from a scale of four. When geography teachers have not used much information and communication technology in the learning process, it can be assumed that they have not been able to integrate content, pedagogy, and learning technology, which in turn also cast doubt on their readiness in facing the industry 4.0 era.

\section{THEORETICAL FRAMEWORK Concept of TPACK}

Theoretically, TPACK is knowledge about how to facilitate learning through effective, interesting, and efficient learning approaches with the use of technology that is currently developing [10] [11] [12]. Another opinion also said that TPACK is a professional framework of a teacher who is believed to help teachers in integrating Information Communication Technology (ICT) into teaching and learning activities in the classroom [13].

The TPACK concept is a refinement of the existing concept namely Pedagogical Content Knowledge (PCK) which was initiated by Shulman in 1986 [14]. Initially, the term often used was TPCK but changed to TPACK to make it easier to pronounce [15]. TPACK concept formulation is a framework for integrating technology in teaching [11], in response to the rapid development of technology in learning. In the concept level, TPACK has three main studies, namely Technological Knowledge, Content Knowledge, and Pedagogical Knowledge, also the interaction between each of the two knowledge and between all of these knowledge [16]. The merger will be explained in detail through Figure 1.

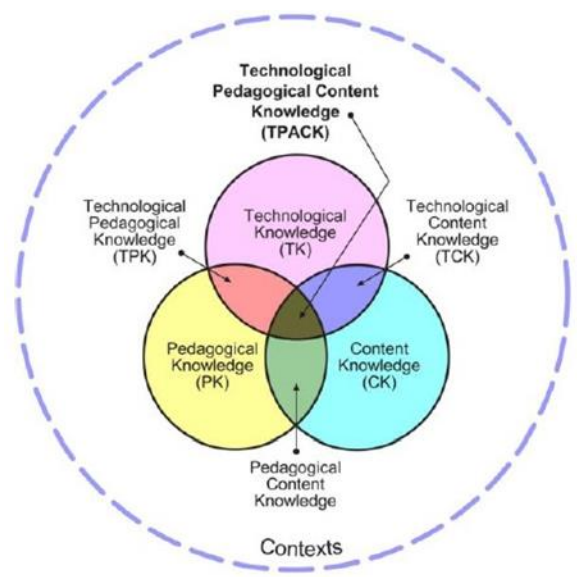

source: Kohler's; 2013

Figure 1. Framwork of TPACK

174 Ahmad Yani, et al.| TPACK Venn Diagram .... 
In the picture above it can be concluded that TPACK is a combination of technological knowledge, pedagogical knowledge, and content knowledge that results in a new slice. The study of TPACK continues to be carried out and finally gave rise to the name Angeli \& Valanides in 2009 which proposed elements of students, context, and ICT in the TPACK framework with a new term namely ITCTPCK; and in 2012 it was conceived to develop another concept, namely TPACK-XL, the idea of interdisciplinary knowledge within the basic framework of TPACK.

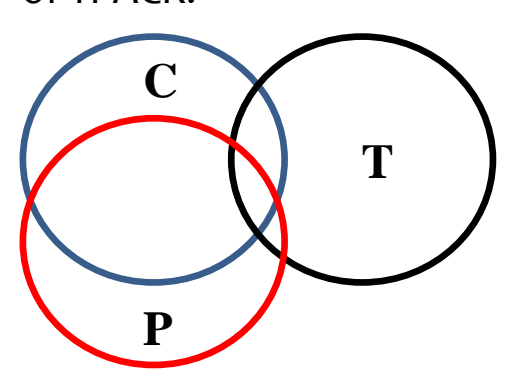

(a)

)

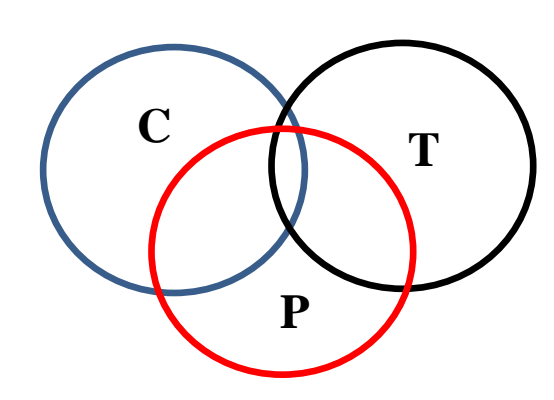

(b)
In this study, each teacher is assumed to be able to measure their understanding and skills in implementing learning based on the TPACK framework. Some teachers may have adequate understanding of subject matter and at the same time have good skills in pedagogical aspects, although they may still be low in utilizing learning technology. Other teachers lack mastery of pedagogical aspects, but are relatively good at using technology. With so many variations on TPACK mastery, it is possible for the teacher profile to be assigned in the form of a TPACK venn diagram as follows:

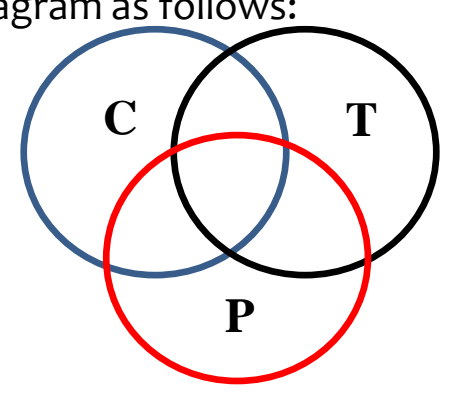

(c)

Sumber: Kohler's; 2013

Gambar 2: Tiga pola diagram venn TPACK.

In the picture above, it can be explained: (a) Content and pedagogical knowledge is quite good but slices with relatively low technological knowledge; (b) knowledge of the content and application of technology is relatively low, but has relatively good pedagogical knowledge; (c) knowledge of content, pedagogy, and technology is relatively balanced by the price.

a. Proportion of TPACK - PCK $=50 \%-50 \%$

b. Proportion of TPACK - TCK $=50 \%-50 \%$

c. Proportion of TPACK - TPK $=50 \%-50 \%$

\section{Characteristics of Geography Subject in 2013 Curriculum}

The characteristics of geography subject are colored by the substance of geography itself. The Rediscovering
Geography Committee which was established in 1993 in the United States in its publication entitled Rediscovering Geography New Relevance for Science and Society explains that "geography's traditional interest in integrating phenomena and processes in particular places" [17], and subsequently has attention to interdependencies between phenomena and processes, both on a small scale and large scale. Rhoad Murphey mentions three broader geographical scopes of study namely distribution, interrelationship, and regional framework [18]. The implications of the characteristics of geography subjects require a learning process that can facilitate students to be able to understand the problem, 
identify the causative factors, and formulate their findings in the form of descriptions and conclusions with certain methods and technologies. The effort is not easy because it takes a more serious effort to be able to make it happen. This research tries to do so.

In the Geography Subject Syllabus document published by the Ministry of Education and Culture explained that geography teachers are required to create a learning process that can facilitate students to be able to understand the problem, identify the causative factors, and formulate their findings in the form of descriptions and conclusions. The recommended learning approach is a scientific-based approach such as inquiry and discovery, problem based learning and project based learning. Scientific learning that is recommended is expected to achieve learning objectives both direct (instructional effect) in the form of Basic Competencies that have been explicitly established, as well as indirect learning outcomes (nurturant effect) in the Core Competencies in the form of spiritual and social aspects. The competences of spiritual and social attitudes are achieved through the personality and professionalism of the teacher in the space such as personal exemplary, habituation of good behavior, and school culture.

\section{RESEARCH METHOD}

The research method used is descriptive survey techniques in data collection. The instruments used were questionnaires and interviews. The location for the questionnaire distribution consisted of West Java Province, Bengkulu Province, and other provinces that were filled in online through Google forms. The subject of the study was the geography teacher with 121 respondents with the following characteristics.

Tabel 1 Profile of Respondents based on the length of teaching experience

\begin{tabular}{lcr}
\hline $\begin{array}{c}\text { Teaching } \\
\text { Experience } \\
\text { (Tahun) }\end{array}$ & Frequency & $\%$ \\
\hline $0-10$ & 66 & 54,55 \\
\hline $11-20$ & 31 & 25,62 \\
\hline $21-30$ & 18 & 14,88 \\
\hline$>30$ & 121 & 4,96 \\
\hline TOTAL & Source: Research, 2018 \\
\hline \multicolumn{4}{c}{ wata } & were & analyzed in \\
accordance & with & research \\
objectives, namely quantitatively. Data \\
obtained through questionnaires were \\
analyzed in a quantitative manner while \\
interview data were carried out \\
qualitatively.
\end{tabular}

\section{RESEARCH RESULTS}

The focus of this research is to know the form of TPACK venn diagram in the implementation of geography learning in the 2013 Curriculum (scientific learning). To obtain the above form, of course, it is necessary to know at least two slices, namely (1) the slice between the content knowledge of the material and scientific learning so that a combination of the "circle" of content knowledge with pedagogical knowledge exists; and (2) the implementation of geography learning by utilizing technology.

\section{Implementation of Scientific Learning}

In learning plan, geography teachers generally follow the order of the material contained in textbooks which further considers the learning methods/strategies and consider the availability of teaching media. The way the teacher determines the order of material can be seen in table 4 . 
Tabel 2. Table on How Teachers Determine Material Order

\begin{tabular}{|c|c|c|c|}
\hline NO & $\begin{array}{c}\text { Determining the order } \\
\text { of teaching material }\end{array}$ & $F$ & $\%$ \\
\hline 1 & $\begin{array}{l}\text { Sequentially according } \\
\text { to the material } \\
\text { contained in the } \\
\text { textbook. }\end{array}$ & 38 & 31,04 \\
\hline 2 & $\begin{array}{l}\text { Consider the learning } \\
\text { methods/strategies to be } \\
\text { applied. }\end{array}$ & 30 & 24,99 \\
\hline 3 & $\begin{array}{l}\text { Consider the availability } \\
\text { of learning media. }\end{array}$ & 24 & 20,64 \\
\hline 4 & $\begin{array}{l}\text { Adapted to events or } \\
\text { issues in the community } \\
\text { (contextual). }\end{array}$ & 23 & 19,10 \\
\hline \multirow[t]{2}{*}{5} & Others & 6 & 4,31 \\
\hline & Total & 121 & \\
\hline
\end{tabular}

Table 2 gives very clear information about how the teacher follows the flow of thought determined by the textbook. In addition, it is also about how the teacher determines the learning plan among the three possibilities between media, material, and learning activities. The following are the habits of the teacher in determining the lesson plan presented in table 3 .

Tabel 3. Teacher Habits in Ordering Learning Plans

\begin{tabular}{clcc}
\hline $\mathbf{N}$ & \multicolumn{1}{c}{ ANSWER } & $\begin{array}{c}\text { FREQU } \\
\text { ENCY }\end{array}$ & $\%$ \\
\hline 1 & $\begin{array}{l}\text { Material } \rightarrow \\
\text { Activity } \rightarrow \text { Media }\end{array}$ & 39 & 32,23 \\
\hline 2 & $\begin{array}{l}\text { Material } \rightarrow \text { Media } \\
\rightarrow \text { Activity }\end{array}$ & 67 & 55,37 \\
\hline 3 & $\begin{array}{l}\text { Activity } \rightarrow \text { Media } \\
\rightarrow \text { Material }\end{array}$ & 0 & - \\
\hline 4 & $\begin{array}{l}\text { Activity } \rightarrow \\
\text { Material } \rightarrow \text { Media }\end{array}$ & 8 & 6,61 \\
\hline 5 & $\begin{array}{l}\text { Media } \rightarrow \text { Activity } \\
\rightarrow \text { Material }\end{array}$ & 3 & 2,48 \\
\hline 6 & $\begin{array}{l}\text { Media } \rightarrow \text { Material } \\
\rightarrow \text { Activity }\end{array}$ & 1 & 0,83 \\
\hline 7 & Do not answer & 3 & 2,48 \\
\hline \multicolumn{3}{c}{ Source: Research, 2018 } \\
\hline
\end{tabular}

Table 3 shows that the role of the media is only as a supporter of learning activities. There are two biggest answer patterns, namely determining the material and then learning planning. The second is determining the material and then considering the available media. This description is enough to inform that the teacher has taken the right action in learning planning.

The implementation of scientific learning in the classroom is very important information in this study. First, it is obtained about the geography teacher's perception of the difficulty level of geography material. 
Tabel 4: Teacher's Perception of the Difficulty Level of Geography Material

\begin{tabular}{|c|c|c|c|c|c|c|c|c|c|c|}
\hline \multirow{3}{*}{ Theme of Material } & \multicolumn{10}{|c|}{ Difficulty level using scientific approach } \\
\hline & \multicolumn{5}{|c|}{ Frequency } & \multicolumn{5}{|c|}{$\%$} \\
\hline & 1 & 2 & 3 & 4 & 5 & 1 & 2 & 3 & 4 & 5 \\
\hline $\begin{array}{l}\text { Basic Knowledge of } \\
\text { Geography }\end{array}$ & 0 & 7 & 22 & 14 & 5 & 0,0 & 14,9 & 45,8 & 29,2 & 10,4 \\
\hline $\begin{array}{l}\text { Steps of Research in } \\
\text { Geography }\end{array}$ & 5 & 12 & 16 & 12 & 3 & 10,5 & 25,0 & 33,3 & 25,0 & 6,3 \\
\hline $\begin{array}{l}\text { Earth as the Space of } \\
\text { Life }\end{array}$ & 0 & 3 & 10 & 25 & 10 & 0,0 & 6,3 & 20,8 & 52,1 & 20,8 \\
\hline $\begin{array}{l}\text { The Dynamics of } \\
\text { Lithosphere and Life }\end{array}$ & 0 & 1 & 9 & 22 & 16 & 0,0 & 2,1 & 18,7 & 45,8 & 33,3 \\
\hline $\begin{array}{l}\text { The Dynamics of } \\
\text { Atmosphere and Life }\end{array}$ & 0 & 2 & 8 & 21 & 17 & 0,0 & 4,2 & 16,6 & 43,8 & 35,4 \\
\hline $\begin{array}{l}\text { The Dynamics of } \\
\text { Hydrosphere and Life }\end{array}$ & 0 & 0 & 8 & 18 & 22 & 0,0 & 0,0 & 16,6 & 37,5 & 45,8 \\
\hline $\begin{array}{l}\text { Distribution of Flora } \\
\text { Fauna in Indonesia \& } \\
\text { the World }\end{array}$ & 0 & 0 & 6 & 20 & 22 & 0,0 & 0,0 & 12,5 & 417 & 45,8 \\
\hline $\begin{array}{l}\text { Condition of Indonesian } \\
\text { Territory }\end{array}$ & 0 & 3 & 13 & 19 & 13 & 0,0 & 6,3 & 27,1 & 39,8 & 27,1 \\
\hline $\begin{array}{l}\text { Distribution of } \\
\text { Indonesian Natural } \\
\text { Resources }\end{array}$ & 0 & 1 & 10 & 23 & 14 & 0,0 & 2,1 & 20,8 & 47,9 & 29,2 \\
\hline Dynamics of Citizenship & 0 & 1 & 12 & 18 & 17 & 0,0 & 2,1 & 25,0 & 37,5 & 35,4 \\
\hline $\begin{array}{l}\text { Cultural Diversity of the } \\
\text { Nation }\end{array}$ & 0 & 1 & 11 & 19 & 17 & 0,0 & 2,1 & 22,9 & 39,5 & 35,4 \\
\hline National Food Security & 1 & 7 & 11 & 15 & 14 & 2,1 & 14,6 & 22,9 & 31,3 & 29,4 \\
\hline $\begin{array}{l}\text { Mitigation of Natural } \\
\text { Disaster Adaptation }\end{array}$ & 1 & 2 & 10 & 17 & 19 & 2,1 & 4,2 & 20,8 & 35,4 & 39,9 \\
\hline $\begin{array}{l}\text { Area and Regional } \\
\text { Concepts }\end{array}$ & 2 & 3 & 19 & 13 & 11 & 4,2 & 6,3 & 39,6 & 27,1 & 22,9 \\
\hline $\begin{array}{l}\text { Mapping, Sensing, and } \\
\text { SIG }\end{array}$ & 8 & 16 & 15 & 4 & 5 & 16,7 & 33,3 & 31,3 & 8,3 & 10,4 \\
\hline $\begin{array}{l}\text { Distribution Patterns } \\
\text { and Spatial Interactions }\end{array}$ & 0 & 6 & 23 & 14 & 5 & 0,0 & 12,5 & 47,9 & 29,2 & 10,4 \\
\hline $\begin{array}{l}\text { Developed and } \\
\text { Developing Countries }\end{array}$ & 1 & 3 & 10 & 11 & 22 & 2,1 & 6,3 & 20,8 & 22,9 & 45,8 \\
\hline & 18 & 68 & 213 & 285 & 232 & & & & & \\
\hline
\end{tabular}

Source: Research, 2018

Notes:

1. $=$ Very difficult

2. = Difficult

3. = Can be attempted (although it is difficult)

4. = Easy

5. = Very easy

Furthermore, it was explored about learning barriers and several learning barriers were identified, namely (1) Limited media/learning tools (maps, globe, aerial photographs, etc.), (2) Lack of mastery of a number of subjects in geography teaching materials, (3) Lack of understanding about the practice of implementing a scientific approach, (4) Limited learning resources (textbooks, references, etc.), and (5) Limitations of learning facilities (libraries, laboratories, internet networks, etc.). Data on teacher opinions about learning barriers can be seen in table 5 .

178 Ahmad Yani, et al.| TPACK Venn Diagram .... 

Tabel 5. Teacher's Opinion About Learning Barriers

\begin{tabular}{ccccccc}
\hline Code & $\%$ & $\begin{array}{c}\text { Limitations of } \\
\text { media/learning } \\
\text { tools }\end{array}$ & $\begin{array}{c}\text { Lack of } \\
\text { mastering } \\
\text { some of the } \\
\text { subject } \\
\text { matter of } \\
\text { teaching } \\
\text { material }\end{array}$ & $\begin{array}{c}\text { Lack of } \\
\text { understanding } \\
\text { about the } \\
\text { practice of } \\
\text { implementing } \\
\text { a scientific } \\
\text { approach }\end{array}$ & $\begin{array}{c}\text { Limited } \\
\text { learning } \\
\text { resources }\end{array}$ & $\begin{array}{c}\text { Limited } \\
\text { learning } \\
\text { facilities }\end{array}$ \\
\hline 1 & $<20 \%$ & 23 & 52 & 32 & 35 & 34 \\
\hline 2 & $21-40 \%$ & 26 & 46 & 45 & 38 & 40 \\
\hline 3 & $41-60 \%$ & 42 & 14 & 32 & 34 & 20 \\
\hline 4 & $61-80 \%$ & 19 & 8 & 12 & 9 & 19 \\
\hline 5 & $>80 \%$ & 11 & 1 & 0 & 121 & 121 \\
\hline
\end{tabular}

Based on the results of the study, it appears that the limitations of the media are felt by many teachers. The factors caused by the lack of mastering the subject are not too significant.

\section{Implementation of Technology in Learning}

Before digging up the information about the use of technology, research looks for the availability of tools, media, and learning technology available in schools. Consider the following Table 6:

Tabel 6. Textbook Ownership and Internet Access

\begin{tabular}{|c|c|c|c|c|c|}
\hline \multirow{2}{*}{$\begin{array}{l}\mathbf{N} \\
\mathbf{0}\end{array}$} & \multirow{2}{*}{$\begin{array}{l}\text { Material } \\
\text { Type }\end{array}$} & \multicolumn{2}{|c|}{$\begin{array}{l}\text { Average Number } \\
\text { of Ownership by } \\
\text { Teachers }\end{array}$} & \multicolumn{2}{|c|}{$\begin{array}{l}\text { Average Number } \\
\text { of Ownership by } \\
\text { Students }\end{array}$} \\
\hline & & $\mathbf{F}$ & $\begin{array}{l}\text { \% of the } \\
\text { expected } \\
\text { amount (4-6 } \\
\text { pieces) }\end{array}$ & $\mathbf{F}$ & $\begin{array}{l}\text { \% of the } \\
\text { expected } \\
\text { amount (4-6 } \\
\text { pieces) }\end{array}$ \\
\hline 1 & $\begin{array}{l}\text { Textboo } \\
\mathrm{k}\end{array}$ & $\begin{array}{l}1, \\
7 \\
9 \\
\end{array}$ & 44,83 & $\begin{array}{l}1, \\
5 \\
0\end{array}$ & 37,40 \\
\hline 2 & $\begin{array}{l}\text { Enrichm } \\
\text { ent Book }\end{array}$ & $\begin{array}{l}1, \\
4 \\
8\end{array}$ & 36,98 & $\begin{array}{l}1, \\
1 \\
5\end{array}$ & 28,72 \\
\hline 3 & $\begin{array}{l}\text { Referenc } \\
\text { e Book }\end{array}$ & $\begin{array}{l}1, \\
9 \\
4\end{array}$ & 48,55 & $\begin{array}{l}0, \\
7 \\
2\end{array}$ & 17,98 \\
\hline 4 & $\begin{array}{l}\text { Internet } \\
\text { access }\end{array}$ & $\begin{array}{l}1, \\
53\end{array}$ & 38,22 & $\begin{array}{l}1, \\
0 \\
8\end{array}$ & 27,07 \\
\hline
\end{tabular}

Source: Research, 2018
Based on Table 6, teachers only had an average of 1.79 units (44.83\% of the expected amount), meaning that they did not reach the expectation limit. The expected amount is between 4 - 6 pieces. The amount of teaching material possessed is relatively lower than that of teachers. The encouraging information is ownership of internet access because it has the potential to assist in the implementation of TPACKbased scientific learning. Furthermore, a general description of the ownership of tools, media, and technology owned by schools can be seen in table 7 . 

Tabel 7. Ownership of Tools, Media and Technology that Supports Geography Learning

\begin{tabular}{clcc}
\hline No & \multicolumn{1}{c}{$\begin{array}{c}\text { Tools, Media and } \\
\text { Technology }\end{array}$} & $\mathbf{F}$ & $\begin{array}{c}\text { Average Ownership } \\
\text { \% of the expected amount } \\
\text { (4 - 6 pieces) }\end{array}$ \\
\cline { 3 - 4 } & Atlas & 1,8 & 45,04 \\
\hline 2 & Laptop & 1,8 & 44,63 \\
\hline 3 & Desktop computer & 1,8 & 44,42 \\
\hline 4 & Globe & 1,7 & 43,60 \\
\hline 5 & Map of Indonesia & 1,7 & 43,60 \\
\hline 6 & LCD & 1,7 & 42,15 \\
\hline 7 & Internet access & 1,6 & 40,08 \\
\hline 8 & Compass & 1,2 & 29,34 \\
\hline 9 & Image/Chart & 1,0 & 25,83 \\
\hline 10 & Rock Comparator & 1,0 & 24,59 \\
\hline 11 & Topographic maps & 0,8 & 18,80 \\
\hline 12 & GPS & 0,5 & 12,19 \\
\hline 13 & Aerial Photos & 0,3 & 8,68 \\
\hline 14 & Props & 0,3 & 8,06 \\
\hline 15 & Mockups & 0,3 & 7,85 \\
\hline 16 & Stereoscope & 0,3 & 7,02 \\
\hline & & & Source: Research, 2018
\end{tabular}

Based on table 7, it can be seen that the media available in schools are relatively inadequate in terms of tools, media, and learning technology for geography. The tools, media, and technology that the school has are all about the atlas, desktop computers, maps, LCD, internet access, compasses, and chart images. Meanwhile, tools, media, and technology that are more specialized than those are not yet available. This is a separate note, due to the low application of TPACK in schools. Based on the results of the interview, the age of the teacher is a determining factor in the implementation of TPACK. The age of teachers who are still young are millennial generations, therefore they are already accustomed to using the internet. Based on secondary data there are 54.86 percent of Indonesians who have been connected to the internet. From these data, the most internet users are millennials, whose age ranges from 19 years to 34 years
(49.52\%); The age group is $35-54$ (29.55\%), the group is $13-18$ years (16.68\%) and the age is more than 54 years (4.24\%) (kumparan.com, 2018). This data shows that geography teachers are now almost entirely internet literate.

The main weakness factor is the availability of geography learning tools/media. The trend in the development of geography learning tools/media still revolves around two, namely atlases, maps of Indonesia and the globe. Then, after the last 10 years appear complete LCD media, laptops, and the internet. Other tools/media and technologies are not yet available such as compasses, GPS, field survey equipment, remote sensing technology, SIG, and others. In geography, tools and media are not just tools, but become "learning material". For example, a map has two functions, namely as a learning aid and also learning material when the 
map is used as practice material for problem analysis.

Based on information gathering through interviews, the 1st research subject that can be found in Sumedang Regency said:

"My experience is the limited projector to teach. I have prepared presentation materials for teaching in class. But when going to class, it turns out the projector is not available. Finally I replaced the learning method that was originally a lecture with presentation material (power point) into a discussion method. To get tools and materials, sometimes my school doesn't have information to get those tools and materials. So that the desired tools and materials do not match the tools and materials needed."

In other places, researchers also obtained information from the 2nd subject that they realized and understood the importance of learning technology, but in schools were not yet completely available:

"With the limitations of existing learning tools, the learning method used is also relied on the availability of tools. For example, if weather and climate measurement tools are available, the learning method used is practice."

When technology is chosen, it will be considered whether it changes teaching methods, for example, classroom management, and patterns of interacting with students. The 3rd subject says:

"... using e-module technology that can be accessed on Android will change teaching methods from conventional to technology-based. Interaction will change from discussion to independent learning in inquiry. Assessment will change higher, because the enthusiasm of learners will increase."

The 4th subject reinforces the assumption that respondents basically understand the importance of learning technology and influences the learning approach by saying that:

"... the use of technology will change the method of learning, which was originally a teacher center into a student center."

\section{Hypothetical Forms of TPACK Venn Diagram for Geography Learning}

Based on the results of the research above, it can be concluded that basically the geography teacher is in charge of teaching materials (content) and is able to deliver using methods that are in accordance with the educational process standards. TPACK venn diagram slices that are formed quite well. However, if you look at the lack of availability of learning technology in schools, it can be suspected that the intersection between the pedagogical and technological areas is less significant. By paying attention to the three elements above, hypothetically, the form of a TPACK venn diagram of geography learning in 2013 Curriculum as of this writing is shown in Figure 3. How to read it, TPACK is considered an aggregate of three components (knowledge of content, pedagogy, and technology) that have a price constant one (1) will thus be drawn:

Proportion of TPACK : PCK $=25 \%: 75 \%$

Proportion of TPACK : TCK $=25 \%: 35 \%$

Proportion of TPACK : TPK $=25 \%: 15 \%$ 


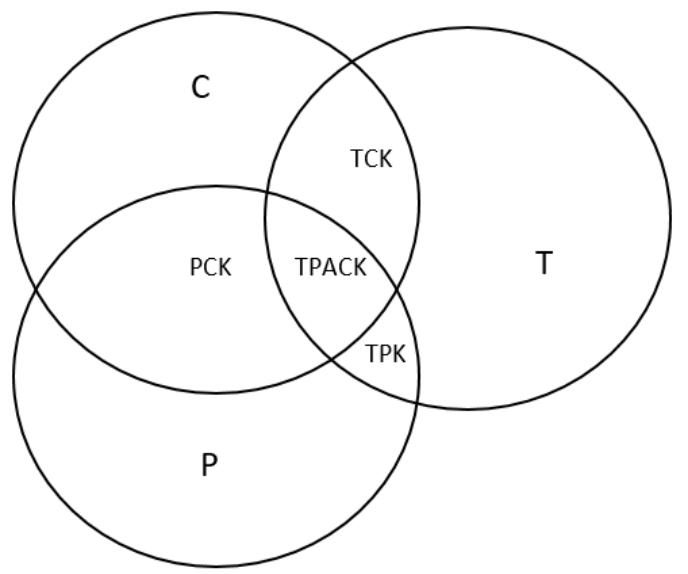

Figure 3: Hypothetical forms of TPACK venn diagram on the implementation of Geography Learning in 2013 Curriculum

\section{CONCLUSIONS}

Based on the results of the study, it can be concluded that the hypothetical form of TPACK venn diagram can be used as a visualization of the balance of the knowledge of content, pedagogy, and technology in each implementation of the learning process. The ideal TPACK slice area is balanced starting from $50 \%$ of the PCK, TPK or TCK slice area. This means that the teacher masters TPACK optimally. However, the area of TPACK can also be narrowed $(<50 \%)$ which requires limited TPACK mastery. The implications of the unbalanced TPACK venn diagram form can be used as a reference in improving teacher competence. In this study, the mastery profile framework of TPACK geography teachers has the slices price of TPACK (25\%), PCK (75\%), TCK (35\%), and TPK (15\%). With this data, the competencies that need to be improved are TCK and TPK slices. If the competency improvement is successful, then TPACK will find the balance later.

\section{REFERENCES}

[1] A. Adiarto, "Metacognition Learning Influences Through an Inquiry Method on Understanding Improvement of
Social Science Education Concepts and Critical Thinking Skills of Students (A Study of Quasi Experiment in Class VII At SMP Negeri 2 Menes Pandeglang)," J. Pendidik. Ilmu Sos., vol. 26, no. 1, p. 8, Jun. 2017.

[2] R. J. Spiro, "Cognitive Flexibility and Hypertext: Theory and Technology for the Nonlinear and Multidimensional Traversal of Complex Subject Matter," pp. 177-220, 2012.

[3] J. Harris, P. Mishra, and M. Koehler, “Teachers' technological pedagogical content knowledge and learning activity types: Curriculum-based technology integration refrained," J. Res. Technol. Educ., vol. 41, no. 4, pp. 393-416, 2009.

[4] L. M. Archambault and J. H. Barnett, "Revisiting technological pedagogical content knowledge: Exploring the TPACK framework," Comput. Educ., vol. 55, no. 4, pp. 1656-1662, 2010.

[5] A. Benešová and J. Tupa, "Requirements for Education and Qualification of People in Industry 4.0," Procedia Manuf., vol. 11, no. June, pp. 2195-2202, 2017.

[6] C. N. Gunawardena, M. S. Mclsaac, and M. S. Mclsaac, "Distance Education," pp. 361401, Jan. 2013.

[7] L. Shulman, "Knowledge and Teaching: Foundations of the New Reform," Harv. Educ. Rev., vol. 57, no. 1, pp. 1-23, Apr. 1987.

[8] I. A. Syukur, "Teacher Professionalism In Implementing Information And Communication Technology In Nganjuk District," J. Pendidik. dan Kebud., vol. 20, no. 2, 2014.

[9] M. Nursa'ban and S. S. Suparmini, 
"Evaluasi Kompetensi Pedagogik Guru Geografi SMA di Kabupaten Bantul," SOCIA J. Ilmu-Ilmu, 2012.

[10] S. Cox and C. R. Graham, "Using an elaborated model of the TPACK framework to analyze and depict teacher knowledge," TechTrends, 2009.

[11] M. J. Koehler and P. Mishra, "Technological Pedagogical Content Knowledge: A Framework for Teacher Knowledge," Teach. Coll. Rec., vol. 108, no. 6, pp. 1017-1054, 2006.

[12] L. S. Shulman, "Those Who Understand: Knowledge Growth in Teaching," Educ. Res., vol. 15, no. 2, pp. 4-14, 1986.

[13] J. Hewitt, "Reviewing the handbook of technological pedagogical content knowledge (TPCK) for educators," Can. J. Sci. Math. Technol. Educ., vol. 8, no. 4, pp. 355-360, 2008.
[14] M. C. Herring, M. J. Koehler, and P. Mishra, Handbook of Technological Pedagogical Content Knowledge (TPACK) for Educators. (2nd edition), vol. 61, no. 4. New York: Routledge, 2016.

[15] C. S. Chai and J. H. L. Koh, "A review of technological pedagogical content knowledge," JSTOR, 2013.

[16] M. J. Koehler, P. Mishra, and W. Cain, "What is Technological Pedagogical Content Knowledge (TPACK)?," J. Educ., vol. 193, no. 3, pp. 13-19, Oct. 2013.

[17] Rediscovering Geography Committee, "Rediscovering geography: New relevance for science and society," 1997.

[18] R. Murphey, The Scope of Geography. Chicago: Rand McNally, 1973. 